\title{
Biological Control of Meloidogyne hapla Using an Antagonistic Bacterium
}

\author{
Jiyeong Park, Yunhee Seo and Young Ho Kim* \\ Department of Agricultural Biotechnology and Research Institute of Agriculture and Life Sciences, Seoul National University, \\ Seoul 151-921, Korea
}

(Received on February 5, 2014; Revised on April 18, 2014; Accepted on April 21, 2014)

We examined the efficacy of a bacterium for biocontrol of the root-knot nematode (RKN) Meloidogyne hapla in carrot (Daucus carota subsp. sativus) and tomato (Solanum lycopersicum). Among 542 bacterial isolates from various soils and plants, the highest nematode mortality was observed for treatments with isolate C17, which was identified as Bacillus cereus based on cultural and morphological characteristics, the Biolog program, and $16 \mathrm{~S}$ rRNA sequencing analyses. The population density and the nematicidal activity of $B$. cereus $\mathrm{C} 1-7$ remained high until the end of culture in brain heart infusion broth, suggesting that it may have sustainable biocontrol potential. In pot experiments, the biocontrol efficacy of $B$. cereus $\mathrm{C} 1-7$ was high, showing complete inhibition of root gall or egg mass formation by RKN in carrot and tomato plants, and subsequently reducing $R K N$ damage and suppressing nematode population growth, respectively. Light microscopy of RKN-infected carrot root tissues treated with C1-7 showed reduced formation of gall cells and fully developed giant cells, while extensive gall cells and fully mature giant cells with prominent cell wall ingrowths formed in the untreated control plants infected with RKNs. These histopathological characteristics may be the result of residual or systemic biocontrol activity of the bacterium, which may coincide with the biocontrol efficacies of nematodes in pots. These results suggest that $B$. cereus $\mathrm{C} 1-7$ can be used as a biocontrol agent for M. hapla.

Keywords : Bacillus cereus, biological control, giant cell, Meloidogyne hapla

*Corresponding author.

Phone) +82-2-880-4675, FAX) +82-2-873-2317

E-mail) yhokim@snu.ac.kr
The total global agricultural damage caused by plantparasitic nematodes is estimated to be $\$ 100$ billion USD per year, among which the most important are root-knot nematodes (RKNs: Meloidogyne spp.; Oka et al., 2000). RKNs are distributed globally, infecting more than 2,000 plant species and reducing global crop yields by about $5 \%$, mainly through root-knot gall formation and nutritional deprivation (Sasser, 1977).

RKNs are commonly controlled by chemicals such as soil fumigant and non-fumigant nematicides; however, these have not been able to achieve full control of RKNs due to the soilborne nature of these nematode pests. In addition, chemical methods are very toxic to humans, animals, and sometimes even plants, and can cause soil and water pollution against which new nematicide production techniques are urgently required (Oka et al., 2000; Osman and Viglierchio, 1981).

Biological control offers a good alternative to chemical control, and provides efficient control with no or little hazard to the soil environment (Noling and Becker, 1994). A variety of microorganisms and natural enemies antagonistic to soil nematodes exist in the soil, including bacteria, fungi, predatory nematodes, and mites. These microbial antagonists and natural enemies are usually found in "nematode-suppressive" soils, in which their damage to plants is below economic threshold levels. Microbes may propagate and spread in the soil for a long time without permeating host plants, and some microbes even enhance plant growth. Therefore, the application of antagonistic soil microbes is expected to effectively control nematodes and act as useful biological control agents against RKNs (Oka et al., 2000).

In Korea, Meloidogyne incognita, $M$. arenaria, and $M$. hapla are the major RKNs. M. incognita and M. arenaria are the most common RKN species distributed in warmer regions such as greenhouse soils in Korea (Kim, 2001; Kim et al., 2001b). However, M. hapla favors cooler temperatures and is widely distributed in open-field soils, decreasing qualitative and quantitative production loss of 
root crops such as ginseng, Codonopsis lanceolata, and carrot in Korea (Kim, 2001; Park et al., 1994, 1995). Control of RKNs under greenhouse conditions has been accomplished using cultural and chemical methods, including treatment with nematicides, admixtures of soil, rotation, and flooding (Kim and Choi, 2001; Kim et al., 2001a). These control measures are more effective against $M$. incognita and $M$. arenaria in greenhouse soils than against $M$. hapla in openfield soils because of the confined cultivation of highvalued crops under controlled environmental conditions in greenhouses (Brown, 1978). Studies on breeding or selection of vegetables resistant to $M$. incognita and $M$. arenaria have been conducted, in which several species and lines of vegetables have been used as genetic resources for breeding and controlling RKNs (Kim et al., 2013; Seo et al., 2014).

However, studies on the control of M. hapla have not been conducted using the control measures mentioned above in Korea due to difficulties in their use for crop cultivation under open-field conditions (Brown, 1978). Thus, alternative methods to control M. hapla are required, for which antagonistic soil microbes with high nematicidal activities, rapid multiplication rates, and durable resistance to environmental stresses can be used for sustainable control capacity over a long period under open-field conditions. Therefore, the purpose of this study was to identify soil microbes that can function as biocontrol agents for M. hapla through in vitro selection of antagonistic microorganisms, and to investigate their biocontrol efficiency in vivo against RKNs. This environmentally friendly method to control RKNs may be applicable to current situations in which carrots are being damaged by the pest M. hapla (Seo et al., 2014).

\section{Materials and methods}

Preparation of nematode inoculum. RKNs used in these experiments were isolated from root galls of ginseng cultivated in Jinan, Jeon-buk Province, Korea, and identified as Meloidogyne hapla based on analysis of 28S rRNA sequences following the method described by Oh et al. (2009; Kim, unpublished data). Four-week-old tomato plants (Solanum lycopersicum cv. Rutgers) grown in a growth chamber were inoculated with second-stage juveniles (J2) of M. hapla and cultivated at approximately $25 \pm 2^{\circ} \mathrm{C}$ in a greenhouse. Seven weeks following inoculation, whenever inoculums were required, tomato plants were uprooted and root systems were carefully washed with running tap water to remove adhered soil. Egg masses of M. hapla were handpicked with the help of the forceps and were placed on a Baermann funnel for 3-5 days to obtain hatched out J2 (Southey, 1986). The inoculum concentrations of J2 were adjusted to required densities using sterile distilled water (SDW), and were employed for in vitro and pot experiments in our study.

In vitro screening of antagonistic bacteria for nematicidal activity against M. hapla. Soil samples were collected from various fields and mountainous areas, from which bacteria were isolated through the dilution plating method (Dhingra and Sinclair, 1985), resulting in a total of 523 bacterial isolates. These bacterial isolates and 19 Paenibacillus strains solated from the 4-year-old Korean ginseng roots with rot symptoms (Jeon et al., 2003); in total, 542 bacteria were subjected to in vitro nematicidal activity screening.

For the first screening bacterial isolates were cultured in brain heart infusion (BHI) broth (BHIB; Conda S.A., Madrid, Spain) at $28^{\circ} \mathrm{C}$ for 2 days agitating at $200 \mathrm{rpm}$ in a shaking incubator. The bacterial cultures were diluted with SDW to concentrations of $2 \%$ and $1 \%$, and then 100 $\mu \mathrm{L}$ of the diluted bacterial culture was transferred to each well of a 96-well Microtest ${ }^{\mathrm{TM}}$ Tissue Culture Plate (Becton Dickinson Labware, Franklin Lakes, NJ, USA) with three replications, into which 50-70 M. hapla J2 were placed. After $24 \mathrm{~h}$ of exposure, M. hapla J2 were examined under a low power stereoscopic microscope, and nematodes were considered dead if they were straight, stiffened, and did not move when probed with a fine needle, compared to flexible and responsive (to the fine needle touch) nematodes that were considered alive (Cayrol et al., 1989).

For the second screening, the bacterial isolates selected in the first screening (based on their high nematicidal activities) were screened again for nematicidal activity using the bacterial cell suspensions without culture filtrate (culture filtrate-free bacterial cell suspensions) that may contain nematicidal compounds produced during culture. For this, the bacterial cultures grown in BHIB at $28^{\circ} \mathrm{C}$ for $48 \mathrm{~h}$ in a shaking incubator (at $200 \mathrm{rpm}$ ) were centrifuged at $5,162 \times g$ to collect bacterial cells in a pellet by removing supernatant from bacterial cultures. The collected bacterial cells in the pellet were suspended in SDW and diluted to the proper concentrations, for which their colony-forming units (CFU) were examined through the dilution plating method (Dhingra and Sinclair, 1985). Nematicidal activity of the bacterial suspensions was examined using $100 \mu \mathrm{L}$ of the bacterial suspensions with concentrations of $1 \times 10^{6} \mathrm{CFU} / \mathrm{mL}$ and $1 \times 10^{8} \mathrm{CFU} / \mathrm{mL}$ using the same methods mentioned in the first screening of bacterial cultures for nematicidal activity. 
Identification of antagonistic bacterium selected by in vitro screening. One bacterium (isolate $\mathrm{C} 1-7$ ) out of 542 bacterial isolates was selected in the first and second screening tests as a potential candidate for the biological control of M. hapla. The bacterium C1-7 was identified based on colony morphology, gram staining, carbon source assimilation, and 16S rRNA gene sequencing analysis. Colony morphology was examined by visualizing the colonies formed after 3 days of culturing on BHI agar. Gram staining was conducted following the method previously described by Schaad et al. (2001). Bacterial morphology was examined under an energy-filtering transmission electron microscope (Libra 120, Carl Zeiss, Oberkochen, Germany) operated at an accelerating voltage of $120 \mathrm{kV}$ following negative staining with $2 \%$ phosphotungstic acid (PTA). Carbon source assimilation of the bacterial isolate was examined with a Biolog GN test kit (Biolog Inc., Hayward, CA, USA). For 16S rRNA gene sequencing analysis, chromosomal DNA was extracted from the 2-day-old bacterial colony on BHI agar using a FastDNA spin kit (MP Biomedicals, Santa Ana, CA, USA). In addition a polymerase chain reaction (PCR) was performed using universal primers $27 \mathrm{mF}$ ( $5^{\prime}$-GAGTTTGATCMTG GCTCAG-3') and 1492mR (5'-GGYTACCTTGTTACG ACTT-3') in a MyCycler Thermal Cycler system (Bio-Rad, Hemel Hempstead, Herts, UK) for the amplification of the16S rRNA gene (Yoon et al., 1998). The amplified PCR products were purified using a Wizard SV Gel and PCR cleanup system (Promega, Madison, WI, USA), and were then used to analyze for 16S rRNA gene sequences with an ABI PRISM BigDye ${ }^{\mathrm{TM}}$ Terminator Cycle Sequencing Kit (Applied Biosystems, Foster City, CA, USA). Results were compared with ribosomal DNA sequences registered in GenBank using a BLASTN program for bacterial identification (Thompson et al., 1994).

Growth characteristics of C1-7 in different culture media. To determine the optimal population density and culture media for the most efficient application of isolate $\mathrm{C} 1$ 7 , growth curves were examined every $6 \mathrm{~h}$ for $114 \mathrm{~h}$ after inoculation on four different media including nutrient broth (NB; Conda S.A.), BHIB, Luria-Bertani (LB) broth (LBB; Difco, Detroit, MI, USA), and Bacto ${ }^{\mathrm{TM}}$ tryptic soy (TS) broth (TSB; Becton, Dickinson and Company, Le Pont de Claix Cedex, France). For this step, the numbers of CFU were examined by the dilution plating method (Dhingra and Sinclair, 1985).

Nematicidal activity of C1-7 cultured in different media. Four different culture media (NB, BHIB, LBB, and TSB) were used to examine bacterial growths and to test for the nematicidal activity of C1-7. One milliliter of bacterial solution was taken from the bacterial culture at intervals of $6 \mathrm{~h}$ after the initial inoculation. Samples were diluted with SDW to various concentrations $(0.5 \%, 1.0 \%, 2.0 \%$, and $5.0 \%$ ), and then $100 \mu \mathrm{L}$ of diluted bacterial solution was transferred to each well of a 96-well Cell Culture Plate (FType; SPL Life Sciences, Pocheon-si, Gyeonggi-do, Korea) into which 50-70 J2 of M. hapla were placed. After 24 $\mathrm{h}$ of exposure, dead and living M. hapla J2 were counted under a low-power stereoscopic microscope as mentioned above in the in vitro screening.

Effect of the bacterial culture filtrate on nematode mortality. The culture filtrate of isolate $\mathrm{C} 1-7$ was also examined for nematicidal activity. The bacterial isolate was grown in BHIB at $28^{\circ} \mathrm{C}$ in a shaking incubator (200 rpm) for $18 \mathrm{~h}$ (just after the end of the exponential growth phase) and $48 \mathrm{~h}$ (in stationary phase). The bacterial cultures were centrifuged at $5,162 \times g$ to separate the culture supernatant from the bacterial cells condensed in pellet, and the culture supernatant was filtered through a sterilized $0.22-\mu \mathrm{L}$ Millex Filter Unit syringe (Millipore, Bedford, MA, USA). The culture filtrate was subjected to three heat treatment conditions including a no-heat treatment, heat treatment at $80^{\circ} \mathrm{C}$ for $30 \mathrm{~min}$, and heat treatment at $121^{\circ} \mathrm{C}$ for $20 \mathrm{~min}$. Then, each sterilized culture filtrate was diluted with SDW to various concentrations, and $100 \mu \mathrm{L}$ of the diluted culture filtrate was transferred to each well of a 96-well Cell Culture Plate (F-Type) into which 50-70 M. hapla J2 were placed. After each $24 \mathrm{~h}$ and $48 \mathrm{~h}$ of exposure, J2 mortality was examined as above.

Effect of the antagonistic bacterium on the control of $M$. hapla in pot experiments. C1-7 was tested for biological control of M. hapla on host plants, carrot (Daucus carota subsp. sativus) cv. Shinheukjeon-Ochon and tomato, both of which are highly susceptible to the RKNs (Bélair, 1984; Hartman and Sasser, 1985). The carrot is a representative host crop of M. hapla, and control is urgently required for crop cultivation. The tomato cv. Rutgers is also susceptible to M. hapla and other Meloidogyne species (Hartman and Sasser, 1985), and was used for comparison in our study. Four-week-old seedlings were planted in 8-cm-diameter plastic pots that were filled with a sterilized sand-bed soil (1:1) mixture, and each plant was inoculated with M. hapla by dispending $5 \mathrm{~mL}$ of the nematode suspension containing $200 \mathrm{~J} 2 / \mathrm{mL}$ per pot. For the biological control of the nematode, $10 \mathrm{~mL}$ of $\mathrm{C} 1-7$ culture grown in BHIB at $28^{\circ} \mathrm{C}$ in a shaking incubator (200 rpm) for 3 days and diluted with 
SDW to the concentration of $1 \times 10^{8} \mathrm{CFU} / \mathrm{mL}$ was poured around the plant rhizosphere at the same time as nematode inoculation. Plants with neither nematode inoculation nor bacterial treatment served as controls. Fresh BHIB (10 $\mathrm{mL}$; diluted as much as the bacterial culture) was poured around the plant rhizosphere to examine the effect of the medium on nematode control. Each treatment was replicated five times and the pot experiments were conducted at $25 \pm 2^{\circ} \mathrm{C}$ under greenhouse conditions. Plants were watered sufficiently every other day. Four weeks after treatments, plants were carefully uprooted, and root systems were gently washed with running tap water to remove adhered soil. The severity of root galling on plants infected with $M$. hapla was assessed on a $0-5$ rating scale according to the percentage of galled tissues, in which a rating of $0=0-10 \%$ galled roots; $1=11-20 \%, 2=21-50 \%, 3=51-80 \%, 4=$ $81-90 \%$, and $5=91-100 \%$ (Barker, 1985). Egg masses of $M$. hapla were handpicked from infected roots using forceps, and an egg mass index was assigned to each count using a rating scale of $0=$ no egg mass, $1=1-3$ egg masses, $2=4-10$ egg masses, $3=11-30$ egg masses, $4=31-100$ egg masses, $5=>100$ egg masses per root system (Roberts et al., 1990).

Effect of the antagonistic bacterium on histopathological changes in plants infected with M. hapla. Root segments with various degrees of galling were cut off from carrot and tomato roots inoculated with M. hapla, both with and without the bacterial treatment. The root segments were fixed in Karnovsky's fixative consisting of 2\% glutaraldehyde and $2 \%$ paraformaldehyde in $0.05 \mathrm{M}$ cacodylate buffer ( $\mathrm{pH} 7.2$ ) for $48 \mathrm{~h}$ at $4^{\circ} \mathrm{C}$ (Karnovsky, 1965). The fixed specimens were washed in $0.05 \mathrm{M}$ cacodylate buffer $(\mathrm{pH} 7.2)$ at $4^{\circ} \mathrm{C}$ three times each for $10 \mathrm{~min}$. The specimens were then post-fixed in $1 \%$ osmium tetroxide and 0.05 $\mathrm{M}$ cacodylate buffer for $1.5 \mathrm{~h}$ at $4^{\circ} \mathrm{C}$ before brief rinsing with distilled water. After en bloc staining in $0.5 \%$ uranyl acetate for $30 \mathrm{~min}$ at $4^{\circ} \mathrm{C}$, the specimens were dehydrated in an ethanol series of $30 \%, 50 \%, 70 \%, 80 \%$, and $90 \%$ each for $10 \mathrm{~min}$, and finally three times in $100 \%$ ethanol for $10 \mathrm{~min}$ each. For further dehydration, the specimens were treated with propylene oxide at room temperature two times each for $15 \mathrm{~min}$. The specimens were infiltrated with a 2:1 mixture of propylene oxide and Spurr's epoxy resin for $4 \mathrm{~h}$, then a $1: 1$ mixture overnight, followed by $100 \%$ Spurr's epoxy resin under a vacuum for $4 \mathrm{~h}$ in a desiccator. The specimens were embedded in fresh Spurr's epoxy resin in a dental mold, which was placed at $70^{\circ} \mathrm{C}$ for $8 \mathrm{~h}$ in a dry-oven for polymerization. The specimens embedded in the resin were cut to slices of $1,000 \mathrm{~nm}$ thickness with a glass knife on an ultramicrotome (MT-X, RMC, Tucson, AZ, USA). The sections were stained using decuple diluted toluidine blue working solution consisting of $1 \%$ toluidine blue in $2 \%$ sodium borax, and observed under a compound light microscope (Axiophot, Carl Zeiss, Oberkochen, Germany).

\section{Results}

In vitro screening of antagonistic bacteria for nematicidal activity against M. hapla. Under in vitro conditions, the bacterial cultures of a total of 542 bacterial isolates grown in BHIB for $48 \mathrm{~h}$ were diluted to $1.0 \%$ and $2.0 \%$, and screened for nematicidal activity against $M$. hapla. Among these bacterial cultures, 23 bacterial isolates had a high nematicidal activity, providing near to $100 \%$ mortality at $2.0 \%$ concentration (except for two isolates: S-2 and S-4) and was still effective at $1.0 \%$ bacterial isolate (except for three isolates: S-2, S-4, and S-7; Fig. 1A). In the second in vitro screening experiment with culture filtrate-free bacterial cell suspensions at concentrations of $1 \times 10^{6} \mathrm{CFU} /$ $\mathrm{mL}$ and $1 \times 10^{8} \mathrm{CFU} / \mathrm{mL}$, all isolates except for C4-19 and S-5 showed $100 \%$ nematode mortality at a concentration of $1 \times 10^{8} \mathrm{CFU} / \mathrm{mL}$; however, only three isolates $(\mathrm{C} 1-7, \mathrm{~S}-2$, and S-4) provided $100 \%$ mortality at $1 \times 10^{6} \mathrm{CFU} / \mathrm{mL}$ (Fig. $1 \mathrm{~B})$, indicating that isolate $\mathrm{C} 1-7$ had the highest nematicidal activity of $100 \%$ morality at the lowest concentrations of both the bacterial culture and suspension .

Identification of the antagonistic bacterium. C1-7 formed large circular, cream-colored, flat colonies with an undulate margin after 3 days culture on BHI agar (Fig. 2A), and it was gram-positive, rod-shaped, and had more than four peritrichous flagella (Fig. 2B), showing the most similarities with the genus Bacillus (Schaad et al., 2001). The carbon source assimilation of the bacterial isolate examined using a Biolog assay revealed the utilization of 15 carbon sources including glycerol, but not 34 other carbon sources including mannitol, revealing the highest similarity (92.6\%) with Bacillus cereus (data not shown). The analysis of 16S rRNA gene sequences for $\mathrm{C} 1-7$ revealed a maximum similarity $(100 \%)$ to those of $B$. cereus strains listed in GenBank with accession numbers KC113613.1, JX848326.1, JX994144.1, and JX994107.1 (data not shown), including an E-value of 0.0, confirming the bacterium's identity as $B$. cereus.

Growth characteristics of the antagonistic bacterium on different culture media. For all media examined, the lag phase observed in population growth was hardly noted in the culture of the bacterial isolate $\mathrm{C} 1-7$; however, its 


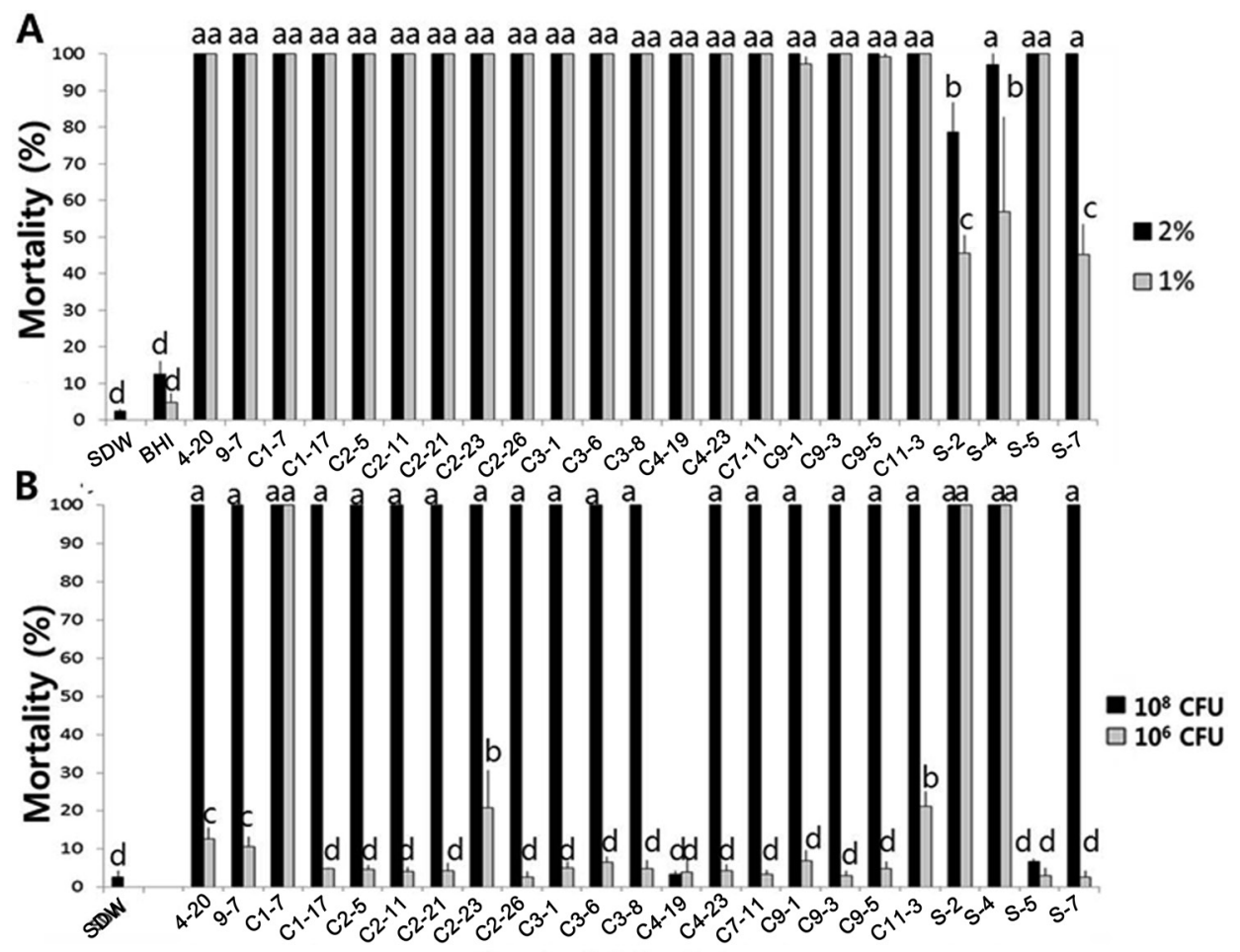

\section{Bacterial isolates}

Fig. 1. First (A) and second (B) in vitro screening for nematicidal activities of bacterial isolates against Meloidogyne hapla in different concentrations of the bacterial cultures (A) and bacterial cell suspensions (B). Bars and vertical lines represent the means and standard deviations of three replications for $M$. hapla $\mathrm{J} 2$ mortality. *, Means with the same letters in each figure denote no significant difference at $P \leq 0.05$ based on Duncan's multiple range test (DMRT).
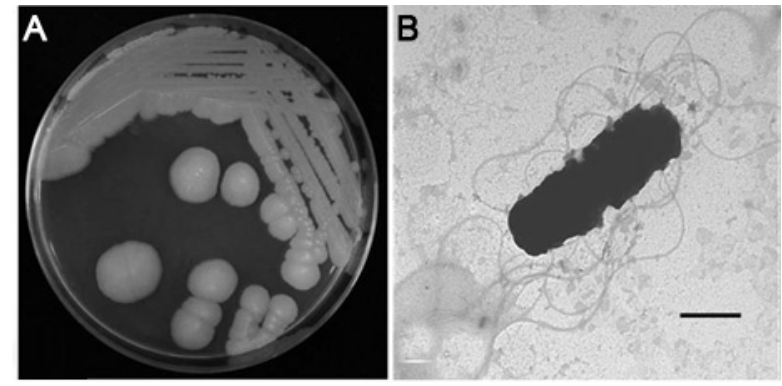

Fig. 2. Cultural (A) and morphological (B) characteristics of the bacterial isolate $\mathrm{C} 1-7$ showing (A) large circular, cream-colored, flat colonies with an undulate margin after 3 days of culture on $\mathrm{BHI}$ agar, and (B) rod-shaped morphology with more than 4 peritrichous flagella revealed by electron microscopy. Bar $=1.0 \mu \mathrm{m}$.

population increased rapidly up to $18 \mathrm{~h}$ after inoculation in all media examined, revealing an exponential phase with populations reaching concentrations of $1 \times 10^{8} \mathrm{CFU} / \mathrm{mL}$ $\sim 1 \times 10^{9} \mathrm{CFU} / \mathrm{mL}$ (Fig. 3). Population growth rates were differentiated after the exponential phase depending on the media, revealing a stationary phase from $36 \mathrm{~h}$ through 60 $\mathrm{h}$ after inoculation (or to the end of culturing with no death

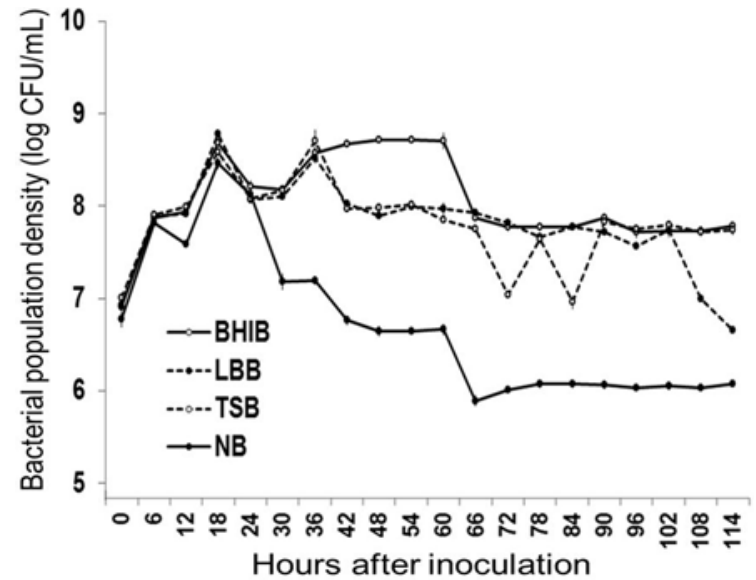

Fig. 3. Population growth curves of the bacterial isolate $\mathrm{C} 1-7$ with the time after culturing in different media including brain heart infusion broth (BHIB), Luria-Bertani broth (LBB), tryptic soy broth (TSB), and nutrient broth (NB). Vertical lines denote standard deviations of three replications.

phase) in all but NB, maintaining a bacterial density of approximately $0.5 \times 10^{9} \mathrm{CFU} / \mathrm{mL}$ in BHIB and approximately $1.0 \times 10^{8} \mathrm{CFU} / \mathrm{mL}$ in LBB and TSB. In NB, the bacterial 
Table 1. Nematicidal activity of Bacillus cereus C1-7 cultured in different media against Meloidogyne hapla

\begin{tabular}{|c|c|c|c|c|c|c|c|c|c|c|c|c|c|c|c|c|c|c|c|c|}
\hline \multirow{2}{*}{\multicolumn{2}{|c|}{$\begin{array}{l}\text { Medium } \\
\text { Con. }\end{array}$}} & \multicolumn{19}{|c|}{ Culture time (h) } \\
\hline & & 6 & 12 & 18 & 24 & 30 & 36 & 42 & 48 & 54 & 60 & 66 & 72 & 78 & 84 & 90 & 96 & 102 & 108 & 114 \\
\hline \multirow{4}{*}{ NB } & $0.5 \%$ & -- & & -- & -- & -- & -- & -- & - & -- & - & & & . & 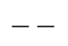 & -- & & -- & - & -- \\
\hline & $2.0 \%$ & -- & -- & -- & -- & -- & -- & -- & -- & -- & -- & -- & -- & -- & -- & -- & -- & -- & -- & -- \\
\hline & $1.0 \%$ & -- & -- & -- & -- & -- & -- & -- & -- & -- & -- & -- & -- & -- & -- & -- & -- & -- & -- & -- \\
\hline & $0.5 \%$ & -- & -- & -- & -- & -- & -- & -- & -- & -- & -- & -- & -- & -- & -- & -- & -- & -- & -- & -- \\
\hline \multirow{4}{*}{ BHIB } & & ++ & ++ & ++ & ++ & ++ & ++ & ++ & ++ & ++ & ++ & ++ & & & & ++ & & & & ++ \\
\hline & $2.0 \%$ & ++ & ++ & ++ & ++ & ++ & ++ & ++ & ++ & ++ & ++ & ++ & ++ & ++ & ++ & ++ & & ++ & ++ & ++ \\
\hline & $1.0 \%$ & ++ & ++ & ++ & ++ & ++ & ++ & ++ & ++ & ++ & ++ & ++ & ++ & + & + & ++ & + & + & ++ & ++ \\
\hline & $0.5 \%$ & -- & -- & -- & -- & -- & -- & - & _ & -- & . & & - & & & -- & & & - & -- \\
\hline \multirow{4}{*}{ LBB } & $5.0 \%$ & ++ & & ++ & ++ & ++ & ++ & & & & & & & & & & & & & ++ \\
\hline & $2.0 \%$ & - & -- & -- & ++ & + & -- & -- & -- & - & -- & + & - & -- & -- & -- & - & -- & -- & -- \\
\hline & $1.0 \%$ & -- & -- & -- & -- & -- & -- & -- & -- & -- & -- & -- & -- & -- & -- & -- & -- & -- & -- & -- \\
\hline & $0.5 \%$ & -- & -- & -- & -- & -- & -- & -- & -- & -- & -- & -- & -- & -- & -- & -- & -- & -- & -- & -- \\
\hline \multirow{4}{*}{ TSB } & $5.0 \%$ & ++ & ++ & ++ & ++ & ++ & ++ & & ++ & ++ & ++ & ++ & ++ & ++ & & ++ & & & ++ & ++ \\
\hline & $2.0 \%$ & ++ & ++ & ++ & ++ & ++ & ++ & ++ & ++ & ++ & ++ & ++ & ++ & ++ & ++ & ++ & ++ & ++ & ++ & ++ \\
\hline & $1.0 \%$ & ++ & ++ & ++ & ++ & ++ & + & + & ++ & ++ & -- & -- & - & - & -- & -- & -- & - & -- & -- \\
\hline & $0.5 \%$ & -- & -- & -- & -- & -- & -- & -- & -- & -- & -- & -- & -- & -- & -- & -- & -- & -- & -- & -- \\
\hline
\end{tabular}

${ }^{*}$ Nematicidal activity was assessed according to the percentage of $\mathrm{J} 2$ mortality in which $--=0-24 \%$ mortality, $-=25-49 \%,+=50-74 \%,++=$ 75-100\%.

population decreased significantly after the exponential growth phase, with no noticeable duration of the stationary phase, to a final population of less than $1.0 \times 10^{6} \mathrm{CFU} / \mathrm{mL}$.

Nematicidal activity of the antagonistic bacterium cultured in different media. No nematicidal activity was observed for the bacterial cultures at all concentrations of NB and at the concentration of $0.5 \%$ of all culture media used in this study (Table 1). Only $5.0 \%$ of the bacterial cultures in LBB and $2.0 \%$ and $5.0 \%$ in TSB showed sufficiently high nematicidal activity throughout the culturing period, while all concentrations except for $0.5 \%$ in BHIB showed high nematicidal activity throughout the culturing period, indicating that BHIB is the optimal medium for the growth of $1-7$ for the nematicidal activity.

Nematicidal activity of the bacterial culture filtrate with different culture times, heating temperatures, and treatment times. The bacterial culture filtrate displayed much higher nematicidal activity against $M$. hapla than either BHI or the control (SDW), regardless of culture time, heating temperature, and time exposed to heating (Table 2). The culture filtrate of the bacterial isolate using an 18-h culture time showed no significant difference in nematicidal activity against $M$. hapla $\mathrm{J} 2$ between the exposure times of $24 \mathrm{~h}$ and $48 \mathrm{~h}$, regardless of heating temperatures, displaying nearly total nematode mortality at concentrations of $2 \%$ and greater. However, the nematicidal activity of the bacterial culture filtrate using a 48-h culture time was higher using an exposure time of $48 \mathrm{~h}$ compared to one of $24 \mathrm{~h}$. Total nematode mortality was observed at a concentration of $1 \%$ using a treatment time of $48 \mathrm{~h}$, but not with a treatment time of $24 \mathrm{~h}$, for both of which no significant differences in nematicidal activity were detected among the heating temperatures (Table 2).

Effect of the antagonistic bacterium on the control of M. hapla in pot experiments. In the pot experiments under greenhouse conditions, root-knot galls and egg masses formed on carrot and tomato plants inoculated with $M$. hapla were significantly suppressed by treatment with the C1-7 bacterial culture $\left(1 \times 10^{8} \mathrm{CFU} / \mathrm{mL}\right)$, illustrating that the size of root-knot galls and the number of root-knot galls and egg masses significantly decreased in the C1-7 treatment compared to the nontreatment control (Table 3, Fig. 4). For root-knot gall formation, complete suppression happened in tomato, while for egg mass formation, complete suppression occurred only in carrot; however, $90 \%$ suppression of root galling was observed in carrot and $75 \%$ suppression of egg mass formation was observed in tomato (Table 3). BHIB treatment also reduced root galling and egg mass formation, especially significantly egg mass 
Table 2. Nematicidal activity of culture filtrate C1-7 at various concentrations depending on culture time, treatment time, and heating temperature against Meloidogyne hapla $\mathrm{J} 2$

\begin{tabular}{|c|c|c|c|c|c|c|c|c|}
\hline \multirow{2}{*}{ Treatment } & \multirow{2}{*}{$\begin{array}{l}\text { Culture } \\
\text { time }(\mathrm{h})^{\mathrm{a}}\end{array}$} & \multirow{2}{*}{$\begin{array}{l}\text { Exposure } \\
\text { time }(\mathrm{h})^{\mathrm{b}}\end{array}$} & \multirow{2}{*}{$\begin{array}{l}\text { Heating } \\
\text { temp. }\left({ }^{\circ} \mathrm{C}\right)^{\mathrm{c}}\end{array}$} & \multicolumn{5}{|c|}{ Nematicidal rates by concentrations } \\
\hline & & & & $10 \%$ & $5 \%$ & $2 \%$ & $1 \%$ & $0.5 \%$ \\
\hline \multirow{12}{*}{$\mathrm{C} 1-7$} & \multirow{6}{*}{18} & \multirow{3}{*}{24} & None & $100 \pm 0.0$ & $100 \pm 0.0$ & $100 \pm 0.0$ & $4.0 \pm 3.0$ & $1.5 \pm 1.5$ \\
\hline & & & 80 & $100 \pm 0.0$ & $100 \pm 0.0$ & $100 \pm 0.0$ & $5.0 \pm 1.4$ & $1.4 \pm 1.3$ \\
\hline & & & 121 & $100 \pm 0.0$ & $100 \pm 0.0$ & $100 \pm 0.0$ & $3.0 \pm 2.8$ & $0.6 \pm 1.0$ \\
\hline & & \multirow{3}{*}{48} & None & $100 \pm 0.0$ & $100 \pm 0.0$ & $100 \pm 0.0$ & $15.9 \pm 10.0$ & $18.6 \pm 4.4$ \\
\hline & & & 80 & $100 \pm 0.0$ & $100 \pm 0.0$ & $100 \pm 0.0$ & $17.9 \pm 3.8$ & $15.2 \pm 3.7$ \\
\hline & & & 121 & $100 \pm 0.0$ & $100 \pm 0.0$ & $100 \pm 0.0$ & $24.3 \pm 5.1$ & $16.4 \pm 4.9$ \\
\hline & \multirow{6}{*}{48} & \multirow{3}{*}{24} & None & $100 \pm 0.0$ & $100 \pm 0.0$ & $100 \pm 0.0$ & $6.1 \pm 2.5$ & $2.9 \pm 1.0$ \\
\hline & & & 80 & $100 \pm 0.0$ & $100 \pm 0.0$ & $100 \pm 0.0$ & $5.0 \pm 3.9$ & $2.9 \pm 2.2$ \\
\hline & & & 121 & $100 \pm 0.0$ & $100 \pm 0.0$ & $100 \pm 0.0$ & $4.3 \pm 1.0$ & $1.1 \pm 1.0$ \\
\hline & & \multirow{3}{*}{48} & None & $100 \pm 0.0$ & $100 \pm 0.0$ & $100 \pm 0.0$ & $100 \pm 0.0$ & $17.1 \pm 2.2$ \\
\hline & & & 80 & $100 \pm 0.0$ & $100 \pm 0.0$ & $100 \pm 0.0$ & $100 \pm 0.0$ & $18.2 \pm 1.9$ \\
\hline & & & 121 & $100 \pm 0.0$ & $100 \pm 0.0$ & $100 \pm 0.0$ & $100 \pm 0.0$ & $15.5 \pm 3.6$ \\
\hline \multirow{2}{*}{$\mathrm{BHI}$} & & 24 & & $100 \pm 0.0$ & $100 \pm 0.0$ & $80.6 \pm 17.3$ & $5.5 \pm 2.1$ & $1.0 \pm 1.8$ \\
\hline & & 48 & & $100 \pm 0.0$ & $100 \pm 0.0$ & $100 \pm 0.0$ & $24.2 \pm 6.0$ & $18.6 \pm 3.6$ \\
\hline SDW & & $\begin{array}{l}24 \\
48\end{array}$ & & & & $\begin{array}{c}3.4 \pm 1.5 \\
201+40\end{array}$ & & \\
\hline
\end{tabular}

- Figures are averages \pm standard deviations of three replications.

aperiod of time that the bacterial isolate was cultured in beef heart infusion broth (BHIB).

${ }^{b}$ Period of time that the nematode was exposed to the bacterial culture filtrate.

${ }^{\circ}$ Culture filtrate C1-7 was exposed to three heat treatment regime including a no-heat treatment (None), heat treatment at $80^{\circ} \mathrm{C}$ for $30 \mathrm{~min}\left(80^{\circ} \mathrm{C}\right)$, and heat treatment at $121^{\circ} \mathrm{C}$ for $20 \min \left(121^{\circ} \mathrm{C}\right)$.

formation in tomato; however, its control efficacy was far below that of the bacterial culture.

Effect of antagonistic bacterial treatment on histopathological changes in plants infected with M. hapla. In the control plants with no bacterial treatment, numerous large giant cells were formed in carrot and tomato roots infected with M. hapla, which is characterized by cellular hypertrophy with the formation of multiple nuclei and sometimes cell wall ingrowths (Fig. 5). The proliferation of gall cells

Table 3. Effect of C1-7 on the biocontrol of Meloidogyne hapla on carrot and tomato through analyses of root galling and egg mass formation

\begin{tabular}{|c|c|c|c|c|c|c|c|c|}
\hline \multirow{3}{*}{ Treatment } & \multicolumn{4}{|c|}{ Root galling } & \multicolumn{4}{|c|}{ Egg mass formation } \\
\hline & \multicolumn{2}{|c|}{ Carrot } & \multicolumn{2}{|c|}{ Tomato } & \multicolumn{2}{|c|}{ Carrot } & \multicolumn{2}{|c|}{ Tomato } \\
\hline & $\mathrm{GI}^{\mathrm{a}}$ & $\mathrm{CE}^{\mathrm{b}}(\%)$ & GI & CE (\%) & $\mathrm{EMI}^{\mathrm{c}}$ & CE (\%) & EMI & $\mathrm{CE}(\%)$ \\
\hline Control & - & - & - & - & - & - & - & - \\
\hline RKN & $2.0 \pm 0.0 \mathrm{a}^{\mathrm{d}}$ & 0 & $2.0 \pm 0.0 \mathrm{a}^{*}$ & 0 & $1.0 \pm 0.0 \mathrm{a}$ & 0 & $4.0 \pm 0.0 \mathrm{a}$ & 0 \\
\hline $\mathrm{BHI}+\mathrm{RKN}$ & $1.6 \pm 1.1 \mathrm{a}$ & 20 & $2.0 \pm 0.0 \mathrm{a}$ & 0 & $0.6 \pm 0.5 \mathrm{a}$ & 40 & $3.2 \pm 0.4 b$ & 20 \\
\hline $\mathrm{C} 1-7+\mathrm{RKN}$ & $0.2 \pm 0.4 b$ & 90 & $0.0 \pm 0.0 \mathrm{~b}$ & 100 & $0.0 \pm 0.0 \mathrm{~b}$ & 100 & $1.0 \pm 0.7 \mathrm{c}$ & 75 \\
\hline
\end{tabular}

${ }^{\mathrm{a}}$ Gall index $=$ severity of root galling by $M$. hapla assessed on a $0-5$ rating scale according to the percentage of galled tissue in which $0=0-10 \%$ of galled roots, $1=11-20 \%, 2=21-50 \%, 3=51-80 \%, 4=81-90 \%$, and $5=91-100 \%$ (Barker, 1985).

${ }^{b} \mathrm{CE}=$ control effect.

${ }^{c}$ Egg mass index was assigned to each count using a rating of $0=$ no egg mass, $1=1-3$ egg masses, 2 = 4-10 egg masses, 3 = 11-30 egg masses, $4=31-100$ egg masses, and $5=>100$ egg masses per root system (Roberts et al., 1990).

${ }^{\mathrm{d}}$ Averages \pm standard deviations of five replications followed by the same letters are not significantly different at $P \leq 0.05$ by the least significance difference (LSD) test. 

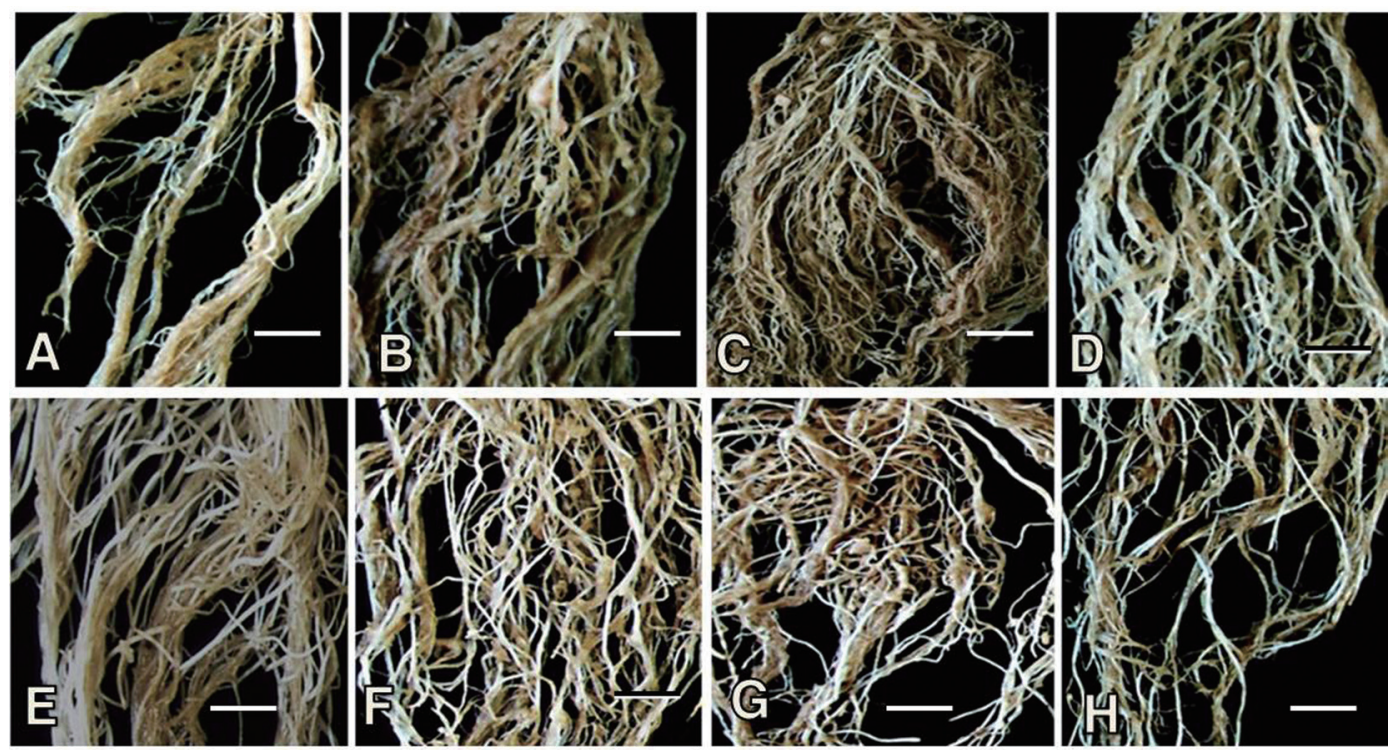

Fig. 4. Effect of C1-7 on root galling caused by Meloidogyne hapla on carrot (A-D) and tomato (E-H). (A and E) No nematode inoculation and no bacterial treatment. (B and F) Nematode inoculation only. (C and G) Nematode inoculation and brain heart infusion broth (BHIB) treatment. (D and H) Nematode inoculation and bacterial treatment. Bars $=2.0 \mathrm{~cm}$.
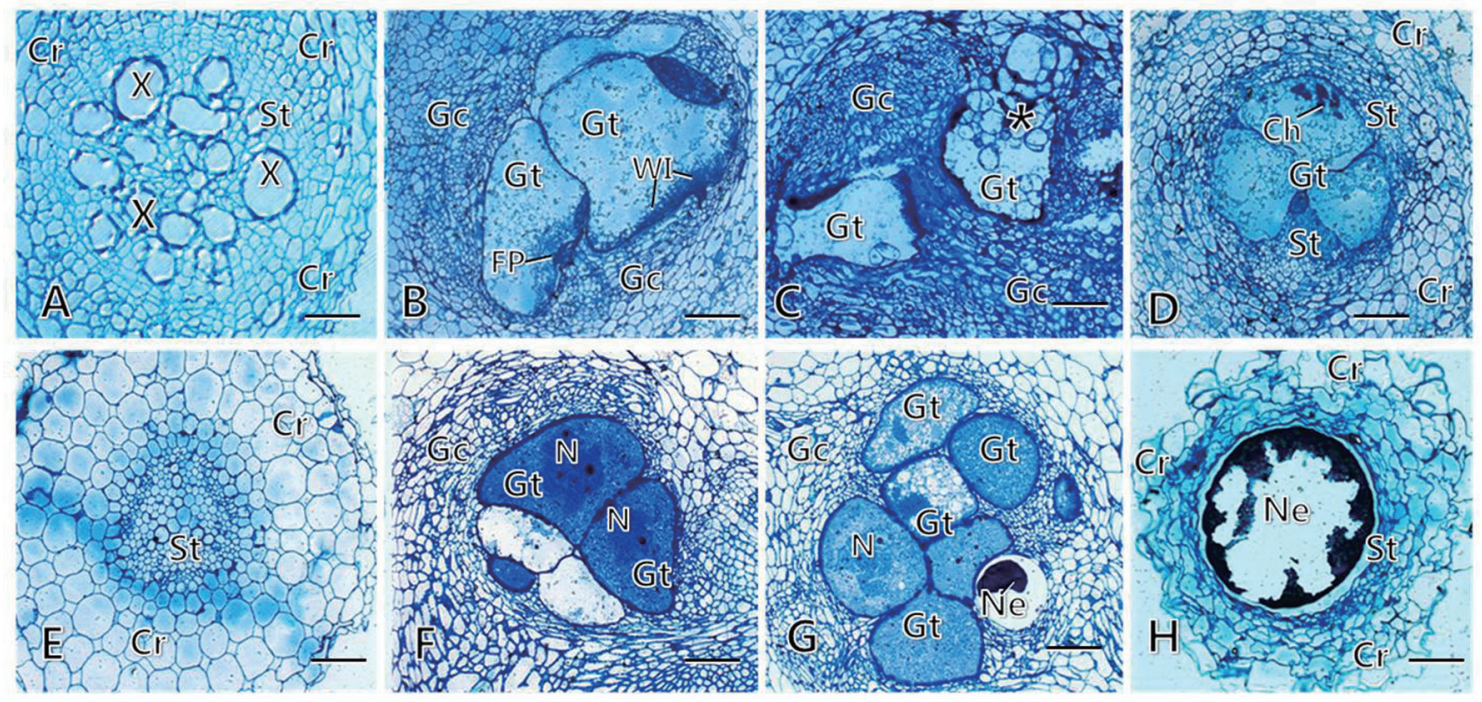

Fig. 5. Light microscopy of structural changes in carrot $(A-D)$ and tomato $(E-H)$ root tissues with no nematode inoculation and bacterial treatment (A, E), influenced by the infection of Meloidogyne hapla alone (B, F), treatments with brain heart infusion broth (BHIB; C, G), and the bacterial culture $(\mathrm{D}, \mathrm{H})$ showing intact root tissues with no nematode infection and no treatment $(\mathrm{A}, \mathrm{E})$; formation of large giant cells (Gt) with feeding plugs (FP), cell wall ingrowths (WI), and numerous nuclei (N) surrounded by proliferated gall cells (Gc; B, F); formation of Gt sometimes degenerative-looking because of cytoplasmic vacuoles (asterisk) with the proliferation of gall cells similar to or less than the nematode inoculation alone $(\mathrm{C}, \mathrm{G})$; and formation of $\mathrm{Gt}$ within the stele, which are degenerative-looking because of the chromatin materials $(\mathrm{Ch})$ scattered in Gt, or no Gt formation with no or minimum formation of $\mathrm{Gc}(\mathrm{D}, \mathrm{H}) . \mathrm{Cr}=\mathrm{cortex}, \mathrm{Ne}=$ nematode, $\mathrm{X}=$ xylem vessel. Bars $=10 \mu \mathrm{m}$.

was noted around the giant cells formed in the roots with no treatment control. Giant cells were also formed in the root tissues infected with the nematode and treated with
BHIB and the bacterial culture; however, they were small in size with no cell wall ingrowths and often appeared degenerative with vacuolar cytoplasm and electron-dense 
materials (presumed to be chromatin materials) scattered in the giant cells (Fig. 5C, D, G). No giant cell formation was found in the nematode-infected tomato root tissues treated with the bacterial culture (Fig. $5 \mathrm{H}$ ). Gall cells proliferated in BHIB to the same extent as the untreated control, but did not proliferate with the bacterial treatment, illustrating that giant cell formation was confined in the stele (Fig. 5D).

\section{Discussion}

M. hapla is one of the major RKNs in Korea, which cause qualitative and quantitative damage in the production of field crops and root vegetables such as ginseng and carrot (Kim, 2001). Numerous microbes such as Bacillus spp., Paecilomyces lilacinus, and Verticillium chlamydosporium have been tested for the control of M. hapla, since they suppress root galling, egg mass formation, egg hatching, and the survival of J2 individuals (Bonants et al., 1995; Chen et al., 2000; De Leij et al., 1993; Liu et al., 2008; Mennan et al., 2006; Townshend et al., 1989; Viaene and Abawi, 2000).

In this study, C1-7 (identified as B. cereus) showed the strongest nematicidal activity in vitro against $M$. hapla among the 523 bacterial isolates tested. Complete nematode mortality was exerted by the bacterial culture and culture filtrate-free bacterial cell suspension at lower concentrations, at which concentration most bacterial isolates (excluding C1-7 and two other isolates) showed no nematicidal activities. This indicates that C1-7 may have exerted nematicidal activity at early treatment times, which would be supported by the rapid bacterial growth and durable nematicidal activity observed during the culture in BHIB.

Furthermore, the culture filtrate of B. cereus C1-7 exerted strong nematicidal activity, suggesting that its mode of action for the biological control of the nematode relies on antibiosis (antagonistic activity of the nematicidal materials produced in the bacterial culture), which is similar to other Bacillus species secreting toxoproteins (Carneiro et al., 1998; Zhang et al., 2012). Thus, B. cereus C1-7 may exert nematode control activity immediately upon application due to the nematicidal compounds produced in the bacterial culture, which is supported by the rapid bacterial growth. This may enhance the overall biological control efficacy, which could provide novel biological control agents (Whipps and Davies, 2000).

Furthermore, unlike the toxoproteins that are usually denatured and deprived of their toxicity by heat shock (Leyns, 1995), the bacterial culture filtrate in our study was heat-stable, similar to non-proteinous thermostable toxic compounds produced by some Bacillus spp. during the stationary phase of bacterial growth (Yu et al., 2012). The population density and the nematicidal activity of $B$. cereus $\mathrm{C} 1-7$ remained high for a long period of time during growth in culture medium. These biological and cultural characteristics of the bacterium may provide some advantages for its formulation and practical application in the biocontrol of RKNs under field conditions owing to the stability and perpetuation of the high nematicidal activity.

In pot experiments, the biocontrol efficacy of $B$. cereus C1-7 was significantly higher in both carrot and tomato plants. However, the specific biocontrol activity against the RKN differed depending on the host plants, demonstrating that the inhibition rates of gall and egg mass formation were higher in tomato and carrot, respectively. This suggests that the biocontrol of M. hapla with B. cereus C1-7 reduces nematode damage and nematode population growth in tomato and carrot, respectively.

Differences in specific biocontrol activity of $B$. cereus C1-7 was also supported by light microscopy of the root tissues infected with the RKN, showing no or few giant cells and gall cells in the tomato and no or few nematodes in the carrot treated with the bacterial culture. This observation agreed with anatomical aspects of tomato plants infected with $M$. incognita, when numerous giant cells formed in large gall tissues with gall cell proliferation, and small giant cells formed in the stele of root tissues without noticeable gall cell proliferation (Kim and Ohh, 1990). Variability of the specific biocontrol activity may be associated with biological characteristics of host plants governing responses to nematode infection, as observed in chili pepper plants infected with M. incognita (Moon et al., 2010) and various host and non-host plants infected with Heterodera glycines (Kim et al., 1986; Kim, 1990). Despite the differences in specific biocontrol activity, these histopathological changes indicate that $B$. cereus $\mathrm{C} 1-7$ has a residual or systemic effect against RKNs infecting root tissues that may have been weakened or escaped from nematicidal activity outside of the root, further increasing the biocontrol efficacy and decreasing the crop yield loss by inhibiting root gall formation (Sasser, 1977).

In this study, the modes of the nematicidal activity of B. cereus C1-7 was not examined in detail; however, one can hypothesize that the reductions in root galling and egg mass formation by M. hapla may be attributable to the direct effects of secondary metabolites that injured the nematode juveniles, or the indirect effects that enhanced host plant defense mechanisms to prevent the nematodes from infection, as found in the plant growth-promoting rhizobacteria Paenibacillus strains (Son et al., 2009). B. cereus is gram-positive, rod-shaped, and genetically close 
to Bacillus thuringiensis, which is commercially used as biological insecticide. Generally, strains of B. cereus are known to be saprophytic and even beneficial as probiotics, representing a promising biological control agent against plant-pathogenic fungi and nematodes (Chang et al., 2007; Handelsman et al., 1990; Huang et al., 2005; Oka et al., 1993; Ryan, 2004; Silva et al., 2004). Some B. cereus strains are harmful to humans and animals, but they are generally known to be self-limiting and noncontagious.

A plant health-promoting rhizobacterium, B. cereus $\mathrm{S} 18$, was tested for the control of $M$. incognita, M. javanica, and $M$. arenaria on tomato and was able to reduce root galls and egg masses along with significant increases in plant growth, including shoot height and weight, when compared to the untreated control (Mahdy et al., 2000). Therefore, $B$. cereus $\mathrm{C} 1-7$ is thought to represent a promising biological control agent against problems caused by $M$. hapla in field crop cultivation.

\section{Acknowledgments}

This study was financially supported in part by the Ministry of Agriculture, Food and Rural Affairs (Project number; 111042-05-3-SB010), Republic of Korea.

\section{References}

Barker, K. R. 1985. Nematode extractions and bioassays. In: An advanced treatise on Meloidogyne, Vol. II. Methodology, ed. by K. R. Barker, C. C. Carter and J. N. Sasser, pp. 19-35. North Carolina State University, Raleigh, NC, USA.

Bélair, C. 1984. Tolerance of carrot cultivars to northern rootknot nematode as influenced by preplant population densities. Phytoprotection 65:69-73.

Bonants, P. J. M., Fitters, P. F. L., Thijs, H., Belder, E. D., Waalwijk, C. and Henfling, J. W. D. M. 1995. A basic serine protease from Paecilomyces lilacinus with biological activity against Meloidogyne hapla eggs. Microbiol. 141:775-784.

Brown, E. B. 1978. Cultural and biological control methods. In: Southey JF, ed. Plant Nematology, $3^{\text {rd }}$ ed. London, UK: Her Majesty's Stationery Office, 269-82.

Carneiro, R. M. D. G., De Souza, I. S. and Belarmino, L. C. 1998. Nematicidal activity of Bacillus spp. strains on juveniles of Meloidogyne javanica. Nematol. Brasileira. 22:12-21.

Cayrol, J. C., Djian, C. and Pijarowski, L. 1989. Study of the nematicidal properties of the culture filtrate of the nematophagous fungus Paecilomyces lilacinus. Rev. Nématol. 12: 331-336.

Chang, W. T., Chen, Y. C. and Jao, C. L. 2007. Antifungal activity and enhancement of plant growth by Bacillus cereus grown on shellfish chitin wastes. Bioresour. Technol. 98:1224-1230.

Chen, J., Abawi, G. S. and Zuckerman, B. M. 2000. Efficacy of
Bacillus thuringiensis, Paecilomyces marquandii, and Streptomyces costaricanus with and without organic amendments against Meloidogyne hapla infecting lettuce. J. Nematol. 32: 70-77.

De Leij, F. A. A. M., Kerry, B. R. and Dennehy, J. A. 1993. Verticillium chlamydosporium as a biological control agent for Meloidogyne incognita and M. hapla in pot and micro-plot tests. Nematologica 39:115-126.

Dhingra, O. D. and Sinclair, J. B. 1985. Basic plant pathology methods. CRC Press, Inc. Boca Raton, FL, USA. 355 pp.

Handelsman, J., Raffel, S., Mester, E. H., Wunderlich, L. and Grau, C. R. 1990. Biological control of damping-off alfalfa seedlings with Bacillus cereus UW85. Appl. Environ. Microbiol. 56:713-718.

Hartman, K. M. and Sasser, J. N. 1985. Identification of Meloidogyne species on the basis of differential host test and perinealpattern morphology. In: An advanced treatise on Meloidogyne, Vol. II. Methodology, ed. by K. R. Barker, C. C. Carter and J. N. Sasser, pp. 69-77. North Carolina State University, Raleigh, NC, USA.

Huang, C. J., Wang, T. K., Chung, S. C. and Chen, C. Y. 2005. Identification of an antifungal chitinase from a potential biocontrol agent, Bacillus cereus 28-9. J. Biochem. Mol. Biol. 38:82-88.

Jeon, Y. H., Chang, S. P., Hwang, J. and Kim, Y. H. 2003. Involvement of growth-promoting rhizobacterium Paenibacillus polymyxa in root rot of stored Korean ginseng. J. Microbiol. Biotechnol. 13:881-891.

Karnovsky, M. J. 1965. A formaldehyde-glutaraldehyde fixative of high osmolarity for use in electron microscopy. J. Cell Biol. 27:137A.

Kim, D., Ryu, Y., Park, H., Huh, C. and Bae, C. 2013. Resistance of commercial tomato cultivars to Meloidogyne arenaria and M. incognita. Res. Plant Dis. 19:25-30 (in Korean).

Kim, D. G. 2001. Occurrence of root-knot nematodes on fruit vegetables under greenhouse conditions in Korea. Res. Plant Dis. 7:69-79 (in Korean).

Kim, D. G. and Choi, S. K. 2001. Effects of incorporation method of nematicides on reproduction of Meloidogyne arenaria. Kor. J. Appl. Entomol. 40:89-95 (in Korean).

Kim, D. G., Choi, D. R. and Lee, S. B. 2001a. Effects of control methods on yields of Oriental melon in fields infested with Meloidogyne arenaria. Res. Plant Dis. 7:42-48 (in Korean).

Kim, D. G., Lee, Y. G. and Park, B. Y. 2001b. Root-knot nematode species distributing in greenhouses and their simple identification. Res. Plant Dis. 7:49-55 (in Korean).

Kim, Y. H. 1990. Structural changes in nonhost response of cowpea and tomato to infection by the soybean cyst nematode. Korean J. Plant Pathol. 6:421-424.

Kim, Y. H. and Ohh, S. H. 1990. Anatomical evidence on the differentiation of xylem vessels around the giant cells induced by the root-knot nematode. Kor. J. Plant Pathol. 6:417-420.

Kim, Y. H., Kim, K. S. and Riggs, R. D. 1986. Morphological characteristics of synchtia in susceptible hosts infected by the 
soybean cyst nematode. Phytopathology 76:913-917.

Leyns, F., Borgonie, G., Arnaut, G. and De Waele, D. 1995. Nematicidal activity of Bacillus thuringiensis isolates. Fundam. Appl. Nematol. 18:211-218.

Liu, T., Wang, L., Duan, Y. X. and Wang, X. 2008. Nematicidal activity of culture filtrate of Beauveria bassiana against Meloidogyne hapla. World J. Microbiol. Biotechnol. 23: 113-118.

Mahdy, M., Hallmann, J. and Sikora, R. A. 2000. Biological control of different species of the root-knot nematode Meloidogyne with the plant health-promoting rhizobacterium Bacillus cereus S18. Com. Agri. Biol. Sci. 65:545-549.

Mennan, S., Chen, S. and Melakeberhan, H. 2006. Suppression of Meloidogyne hapla populations by Hirsutella minnesotensis. Biocont. Sci. Technol. 16:181-193.

Moon, H. S., Khan, Z., Kim, S. G., Son, S. H. and Kim, Y. H. 2010. Biological and structural mechanisms of disease development and resistance in chili pepper infected with the rootknot nematode. Plant Pathol. J. 26:149-153.

Noling, J. W. and Becker, J. O. 1994. The challenge of research and extension to define and implement alternatives to methyl bromide. J. Nematol. 26:573-586.

Oh, H. K., Bae, C. H. Kim, M. I., Wan, X., Oh, S. H., Han, Y. S., Lee, H. B. and Kim, I. 2009. Molecular biological diagnosis of Meloidogyne species occurring in Korea. Plant Pathol. J. 25:247-255.

Oka, Y., Chet, I. and Spiegel, Y. 1993. Control of the root-knot nematode Meloidogyne javanica by Bacillus cereus. Biocont. Sci. Technol. 3:115-126.

Oka, Y., Koltai, H., Bar-Eyal, M., Mor, M., Sharon, E., Chet, I. and Spiegel, Y. 2000. New strategies for the control of plantparasitic nematodes. Pest Manag. Sci. 56:983-988.

Osman, A. A. and Viglierchio, D. R. 1981. Herbicide effects in nematode diseases. J. Nematol. 13:544-546.

Park, S. D., Park, S. D., Choi, B. S. and Choi, Y. E. 1994. Annual phenology of root-knot nematode in the medicinal herb (Paeonia lactiflora) field. Korean J. Appl. Entomol. 33:159-162.

Park, S. D., Park, S. D., Kwon, T. Y., Choi, B. S., Lee, W. S. and Choi, Y. E. 1995. Study on integrated control against rootknot nematode of fruit vegetables (oriental melon and cucumber) in vinyl house. Korean J. Appl. Entomol. 34:75-81.

Roberts, P. A., Dalmasso, A., Cap, G. B. and Castagnone-Sereno, P. 1990. Resistance in Lycopersicon peruvianum to isolates of Mi gene-compatible Meloidogyne populations. J. Nematol. 22:585-589.

Ryan, K. 2004. Plague and other bacterial zoonotic diseases. In: Medical microbiology: An introduction to infectious diseases, $4^{\text {th }}$ ed., ed. by J. C. Sherris, K. J. Ryan and C. G. Ray, pp. 481-491. McGraw-Hill, USA.

Sasser, J. N. 1977. Worldwide dissemination and importance of the root-knot nematodes, Meloidogyne spp. J. Nematol. 9: 26-29.

Schaad, N. W., Jones, J. B. and Chun, W. 2001. Laboratory guide for identification of plant pathogenic bacteria, 3rd ed. APS Press. St Paul, MN, USA.

Seo, Y., Park, J., Kim, Y. S., Park, Y. and Kim, Y. H. 2014. Screening and histopathological characterization of Korean carrot lines for resistance to the root-knot nematode Meloidogyne incognita. Plant Pathol. J. 30:75-81.

Silva, H. S., Romeiro, R. S., Filho, R. C., Pereira, J. L. A., Mizubuti, E. S. G. and Mounteer, A. 2004. Induction of systemic resistance by Bacillus cereus against tomato foliar diseases under field conditions. J. Phytopathol. 152:371-375.

Son, S. H., Khan, Z., Kim, S. G. and Kim, Y. H. 2009. Plant growthpromoting rhizobacteria, Paenibacillus polymyxa and Paenibacillus lentimorbus suppress disease complex caused by root-knot nematode and Fusarium wilt fungus. J. Appl. Microbiol. 107:524-532.

Southey, J. F. 1986. Laboratory methods for work with plant and soil nematodes. Ministry of Agriculture Fisheries and Food. HMSO. London. UK.

Thompson, J. D., Higgins, D. G. and Gibson, T. J. 1994. CLUSTAL W: improving the sensitivity of progressive multiple sequence alignment through sequence weighting, positionspecific gap penalties and weight matrix choice. Nucleic Acids Res. 22:4673-4680.

Townshend, J. C., Meskine, M. and Barron, G. L. 1989. Biological control of Meloidogyne hapla on alfalfa and tomato with the fungus Meria coniospora. J. Nematol. 21:179-183.

Viaene, N. M. and Abawi, G. S. 2000. Hirsutella rhossiliensis and Verticillium chlamydosporium as biocontrol agents of the root-knot nematode Meloidogyne hapla on lettuce. J. Nematol. 32:85-100.

Whipps, J. M. and Davies, K. G. 2000. Success in biological control of plant pathogens and nematodes by microorganisms. In: Gurr G, Wratten S, eds. Biological Control: Measures of Success. London, UK: Kluwer Academic Publishers, 231-70.

Yoon, J. H., Lee, S. T. and Park, Y. H. 1996. Inter-and intraspecific phylogenetic analysis of the genus Nocardioides and related taxa based on 16S rDNA sequences. Int. J. Syst. Bacteriol. 48:187-194.

Yu, Z. Q., Luo, H., Xiong, J., Yin, J., Hu, S. B., Ding, X. Z. and Xia, L. Q. 2012. Identification and nematicidal activity assay on root-knot nematode of a Bacillus strain. J. Agri. Biotechnol. 20:669-675.

Zhang, F., Peng, D., Ye, X., Yu, Z., Hu, Z., Ruan, L. and Sun. M. 2012. In vitro uptake of $140 \mathrm{kDa}$ Bacillus thuringiensis nematicidal crystal proteins by the second stage juvenile of Meloidogyne hapla. PLos One 7:e38534. 